\title{
Courtroom Questioning Adapted to Institutional Power
}

\author{
Haijuan $\mathrm{Hu}$ \\ Correspondence: Haijuan Hu, College of Continuing Education, Guangdong University of Foreign Studies, \\ Guangzhou, China.
}

Received: December 25, 2018

Accepted: January 22, 2019

Online Published: February 12, 2019

doi:10.11114/ijce.v2i1.4050

URL: https://doi.org/10.11114/ijce.v2i1.4050

\begin{abstract}
This paper focuses on analyzing courtroom questioning as a dynamic process of adaptation to the institutional power by recourse to intimidation and topic management. Institutional power is the important factor which motivates the questioners' linguistic choice. By adapting their questioning to the institutional power, questioners can succeed in bringing the defendant, especially the hardened criminals, under their control so that their authority as institutional representatives will be maintained, which is essential to ensure the solemnity and effectiveness of courtroom trial.
\end{abstract}

Keywords: courtroom questioning, institutional power, intimidation, topic management, linguistic choices

\section{Introduction}

This paper is devoted to examining courtroom questioning as an adaptive choice making process. Most previous studies on courtroom interaction are based on Anglo-Saxon jurisdiction, the study of courtroom interaction in China is comparatively few. And most studies (Liao 2003, 2012, 2015; Pan 1997; Sun \& Zhou 1997; Wang 1999; Wu 1995; Yuan 2010) in China took the grammatical or rhetorical approach, which fails to take the dynamics of communication into consideration. The present study proposes an adaptation-based approach to analyze courtroom questioning. The objective of this study is to exam the complexity, functionality and dynamics of the courtroom trials. For the purpose of this study, Chinese data are analyzed in courtroom questioning. All Chinese data are transcripts of several trials in criminal courts, randomly chosen from the 2000-2001 period. The study is conducive to the understanding of the operation of courtroom questioning in general and Chinese courtroom questioning in particular. This paper is made up of four sections. Section one is a brief introduction to the rationale, objective and data collection. Section two introduces several key notions and presents a theoretical framework for the analysis. Section three is devoted to a detailed analysis of the subtlety and complexity of courtroom trials. The major findings of this study are summarized in section four, limitations of the present study and suggestions for future research are also included in the last section.

\section{Key Notions and Conceptual Modal}

This study focuses on courtroom questioning adapted to institutional power. Power is defined as the capacity of one or more persons to produce intended or foreseen effects on others due to authority, manipulation, persuasion or force (Luchjenbroers 1993:139). And power is also understood as the way or process in which the more powerful participants control and constrain the conversational or discoursal contributions of the less powerful participants (Fairclough 1989:46). In courtroom questioning, the power which the questioner wields over the respondent is considerable. This situation is the result of the uneven distribution of power in the courtroom, where, while the defendant or witnesses are stripped down from any type of power and must answer all sorts of questions, institutional representatives are invested with three types of power: socio-cultural power granted by a society that authorizes them to solve disputes; legal power based on the law; and linguistic power that enables them to control the interactional space of conversation, to prompt witnesses to respond, and to pursue answers to the questions they ask (Walker 1987:58).

Institutional power in the present study is understood as the socially and legally sanctioned authority demonstrated in some specific ways of courtroom questioning. The questioner can exercise such power by recourse to intimidation and topic management. Institutional power is one of the most important elements which penetrates the whole process of courtroom questioning. It is embedded in questioners' self-consciousness and they are always sensitive to their position in courtroom trials in general and courtroom questioning in particular. Whenever they fail to control the respondent, they will adapt their questioning to their institutional power. The consciousness in language choice made 
in this way reflects the questioners' 'metapragmatic awareness" (Jacquemet 1994; Verschueren 1999) in the complex questioning process.

Verschueren proposes language use is a process of making linguistic choices and this choice making is motivated by the driving force of making adaptation so as to satisfy the communicator's communicative goals. Courtroom questioning, like other instances of language use, is also driven by adaptation for the sake of satisfying the questioner's communicative goals so as to create a more favorable environment for his survival. Thus courtroom questioning is actually the concrete realization of the questioner's adaptation to the various context or environment for the benefit of satisfying the questioner's communicative goals.

This framework treats courtroom questioning as a process of linguistic choice, which is the fundamental and intrinsic property of language use. All instances of language use are basically a process of choice making. Verschueren (1987:14) argues that using language in general consists of constant linguistic choice making, consciously or unconsciously, for linguistic or extra-linguistic reasons. And the choices are situated at every possible level of linguistic structures. It is based on the variability, negotiability and adaptability of language that linguistic choices can be made to satisfy different communicative needs.

\section{Data Analysis}

\subsection{Resort to Intimidation}

In courtroom trials, most often the defendants feel very nervous because the final judgment of the trial is closely related to their future, even their life. The defendants are worried that the more they confess, the more severe their penalty will be. Even though they know the prosecutor has already got the facts and evidence, they still want to try their luck. Therefore, in answering questions, they try to be evasive, and some hardened criminals even refuse to tell the facts. Under such circumstances, the questioner always adapts his questioning to the institutional power, which can help him bring the defendant under his control.

Extracts(1), (2) and (3) in the following study are taken from the transcription of a criminal case about burning a private car in 2000. In 1999, the defendant contracted with Zhang, another peasant, to jointly operate the coalmine in their village. Out of revenge for the contracting money, the defendant together with his brother burned Zhang's car in the garage on March 3, 2000. And the defendant's brother was severely injured and died on the way to hospital. So the defendant was arrested and charged with destroying property by arson.

(1).

(Courtroom investigation: the prosecutor is questioning the defendant)

Q1：行。就是---你们在这个三月三号, 就是在这个, 这一天, 放火的之前, 就是说, 你们带上都带什么东西 了，七放火之上放火的时候? followup+precursor(time)+Q(what)+residue(modified time)

Q1: All right. That day, March $3^{\text {rd }}$, what did you take with you before you set fire? When you set fire?

A1: 我不知道带什么东西了。Reply=disclaim

A1: I have no idea what we took.

Q2: 当时去的时候带什么东西了? Q-what(repeated)

Q2: What did you take at that time?

$\mathrm{A} 2$ : 当时我不知道。当时他就只是说你跟我办点儿事去, 让我出去。我说上哪儿啊? 他说你别管了。 Reply=disclaim+supply

A2: I don't know then. At that time, he just asked me to go out with him for some affairs. I asked him where we were heading for, and he said that I didn't have to know.

P1: 等会儿啊, 张文祥, 刚才我跟你说了,

P1: Just a minute. Zhang Wenxiang, I told you just now.

A: 恩

A: Yes.

P2: 希望你珍惜今天的机会。(appeal to power)

P2: You are expected to treasure the opportunity.

$\mathrm{A}$ : 是

A: Yes. 
P3: 这种机会不多。(appeal to power)

P3: This kind of opportunity seldom occurs.

$\mathrm{A}$ : 是

A: Yes.

P4: 让你实 $\perp$ 要实事求是讲。(appeal to power)

P4: The court asks you to tell the truth.

$\mathrm{A}$ : 是实事求是。

A: I'm telling the truth.

$(4 \mathrm{~s})$

Q3：你们去时候都带什么东西了? Q-what(repeated)

Q3: What did you take when you went there?

A3: 我、我一概不知。 Reply=disclaim

I don't know anything.

Q4：都带什么东西了? Q-what（repeat the question）

What did you take?

A4: 后来只是出事儿以后我知道---带了靟棍了, 带了那个汽油了 Precursor+answer(comply)

A4: Only after it happened, did I know he had taken the crowbar and gasoline to the spot

In Extract (1), the prosecutor's purpose is plainly to suggest that the defendant should have already known the gasoline and other criminal tools on their way out. So all the four questions in the above extract focus on “你们去时 候都带什么东西了(What did you bring on your way to burning the car)? ”. The defendant insists on claiming that he knows nothing about the case until the actual crime was committed. In A1, the defendant disclaimed his knowledge by replying “不知道 (I don’t know)”. The use of “不知道 (I don’t know)” frustrates the prosecutor employing that version in a series of further questions, so he adapts his questioning by asking Q2 “当时去的时候带 什么东西了? ”, which is a pure repetition of Q1. The same answer “当时我不知道” is provided in A2, but additional explanation follows to justify his "not knowing" as a defense. After being further frustrated by the defendant's “不知道 (I don't know)”, the prosecutor resorts to such threatening speech acts as “希望你珍惜今天的 机会 ( You are expected to treasure the opportunity)” and “这种机会不多 (This kind of opportunity seldom occurs)", which implies that this is the only chance for the defendant to get a lenient punishment so he should take the opportunity to confess his crime. To a certain extent, the two statements can be understood as a persuasion or even an intimidation, i.e. if the defendant refused to tell the truth, he would lose the chance and therefore would receive a severe penalty. The utterance “让你实 $\perp$ 要实事求是讲 (The court asks you to tell the truth)” further reiterates the importance of telling the truth by appealing to the solemnity of the court. In courtroom trial, the defendant is supposed to answer all questions and confess his crime; if he insists on claiming he does not know what he actually knows, he might be labeled as 'contempt of the court' and severe punishment will be considered in the final conviction. So the above three statements function as a threat to the defendant which forces him to tell the truth in A4 “后来只是出事儿以后我知道---带了捼棍了, 带了那个汽油了 (only after it happened, did I know he had taken the crowbar and gasoline to the spot)", which is the result of questioner's successful adaptation to his institutional power.

Compared with Extract (1), the following extract is an example of unsuccessful adaptation by recourse to a similar threatening statement “我再提醒你一句, 啊! 珍上珍惜这 $\perp$ 珍惜今天开庭的机会 (I remind you again, you should treasure the opportunity").

(2).

(The prosecutor is questioning the defendant about the details on their way to the scene of the crime together with his brother)

Q1：车上都有什么? Q-what

Q1: What's in the car on the way to Zhang's garage?

$\mathrm{A} 1$ : 车上我不知道有什么。 Reply=disclaim 


\section{A1: I don't know.}

\section{P1：我再提醒你一句, 啊! (appeal to power)}

P1: I have to remind you again.

$$
\text { A: 恩 }
$$

A: Yes.

\section{P2：珍上珍惜这上珍惜今天开庭的机会。}

P2: You should treasure the opportunity. (4s)

A: 是

A: I see.

$\mathrm{Q} 2$ :我再问你一遍。（2s）去时候你们带什么东西了? preface(metastate)+precursor+Q-what

Q2: I ask you again. What did you take on your way there?

A2: 去时候我不知道带什么东西了, 他只（---）是说跟我出去。我当时我确实没有---跟你上我这确实没跟你 撒谎。Reply=disclaim+explanation + presupposition（metastate）

A2: I didn't know what he took at that time. He only asked me to go out with him. I really had no idea at that time. I did tell you the truth.

Q3：行。下车以后你们都往下拿什么东西了? followup+precursor+Q-what

Q3: That's all right. What did you take out after you got off the car?

A3：他拿了一根儿---他拿了一上递我一副手套。Answer=comply

A3: He handed me a pair of gloves.

Carpenter (1990) observes that during interrogation or courtroom testimony, personal knowledge of events allows guilty suspects or defendants to know which of their statements are potentially self-incriminating and therefore must be phrased with greater caution (cited from Rieber and Stewart 1990:6). Defendants take considerable care to construct their answers so as to best exhibit and support the versions of events they are trying to portray and to avoid endorsing those aspects of prosecutor's versions that differ from or are detrimental to their own versions of the 'facts'.

When the defendant is asked “车上都有什么(What's in the car on the way to Zhang's garage)?”, he continues to display a marked cautiousness about his testimony by replying “我不知道(I don't know)”. In the same case, the prosecutor adapts his questioning into the threatening statement “我再提醒你一句，啊！珍上珍惜这 $\perp$ 珍惜今天开 庭的机会(I have to remind you again. You should treasure the opportunity)”. By resorting to the institutional power he reminds the defendant to treasure the chance and confess his crime. Obviously the defendant is in a dilemma: on one hand, he tries his best to defend himself aiming at a minimum penalty, but if he continues to say "I don't know", the court would mark him as "uncooperative" and therefore he would lose the chance to defend himself. After he carefully chooses a way to present the case for his own benefit in four seconds, he answers “是 (yes)". Then the prosecutor resumes his questioning with a metastatement ${ }^{2}$ “我再问你一遍 (I ask you again)”. In this way, the prosecutor implies that the defendant is unwilling, rather than unable, to answer the question. The same question is reformulated as Q2 “去时候你们带什么东西了(What did you take on your way there)?”. In A2, the defendant replies “去时候我不知道带什么东西了(I didn’t know what he took at that time)” with the further explanation “他 只 (--- ) 是说跟我出去 ( $\mathrm{He}$ only asked me to go out with him)". The defendant ends his reply with a metastatement“我当时我确实没有---跟你上我这确实没跟你撒谎 (I did tell you the truth/ I swear I didn’t lie)” with an attempt to ensure the credibility of his testimony. Further frustrated by the defendant's answer, the prosecutor has to give up with “行 (All right)" as a follow-up in Q3 which is a marker of the adaptation failure in the above questioning. After he reformulates his question as “下车以后你们都往下拿什么东西了? (What did you take out after you got off the car?)", he succeeded in obtaining the desired testimony: “他拿了一根儿---他拿了一上 递我一副手套 (He handed me a pair of gloves).”

\subsection{Resort to Topic Management}

Another way to realize adaptation to the institutional power is demonstrated in the process for the questioners to manage the topic under discussion. Topic management is an important strategy whereby lawyers can dominate witnesses (Conley and O'Barr 1998). On the simplest level, this is an obvious consequence of the fact that questioners ask questions and qustionees answer them. By posing a particular question, one might assume, the questioner determines the topic of the answer. But the reality of topic management is a good deal more complex. A 
court examination is not simply a series of questions followed by topically parallel answers. Instead, whenever the questionee attempts to wander away from the topic, the questioner may then adapt his questioning to the institutional power by specifying the focus with metastatement.

Discussing the impact of metalanguage ${ }^{1}$ in American courtroom interaction, De Leon (cited from Carpenter 1990) points out that metalanguage provides weapons for a strategy that "hegemonizes the verbal space of participants"which is usually"the exclusive right of the most powerful speakers", and that "only the powerful rely on explicit metapragmatic strategies as a form of control". This happens in every context, but in institutional settings such as the courtroom, explicit metapragmatics ${ }^{1}$ becomes a mechanism of control over the communicative expectations of participants (Jacquemet 1994:123). Thomas (1989:133) concludes in one of her studies:

Metadiscoursal comments have several functions. They can be used by the dominant participant in order to keep the subordinate from wandering from that previously established path, by disallowing contributions which do not contribute to the dominant participant's discoursal or social goals.

The data collected for the present study contain several instances in which questioners direct how the respondent is to answer a particular question with some metastatements ${ }^{2}$. While the goal of the prosecutor is to get a confession, the goal of the defendant is to escape accusations, so he often tries to avoid any self-incrimination by deviating from the topic in question. Metastatement is an important adaptation strategy for the prosecutor to specify the focus of testifying by recourse to his institutional power. The following extract is a typical example to illustrate this point.

Q1：再问你一句啊, 那个什么啊, 就是这个面罩的问题。洞是你铰的, 锁没有锁边儿? Preface (metastatement+focus or pusheddown )+precursor +Q（正反）=whole+part

Q1: Another question, about the mask. You made the hole on the mask. Did you stitch the edge?

A1: 没锁边儿。Answer=comply

A1: No, I didn't.

Q2: 锁没锁边? Q (正反) (repeat the question)

Q2: Did you stitch the edge?

A2: 没、没、那个, 拿那个---那个面罩那个布缠, 锁边了, 拿拿线缝的。那个球裤那个不用锁。 Reply (disclaim)+answer+supply (internal residue and external residue)

A2: No. The mask, I stitched the edge of the mask with thread. And the pants were not stitched.

Q3: 我问你面罩呢！metastatement (specifying focus: principle of relevance)

Q3: I'm asking you about the mask.

A3: 啊

A3: What?

Q4: 锁没锁边? 哪窟窟? Q (正反)

Q4: Did you stitch the edge of the hole?

A4: 球裤上面罩那个、那个缝着。Answer=comply

A4: The mask was stitched.

Q5: 谁缝的? Q-who

Q5: Who did that?

A5: 我缝的。Answer=comply

A5: It's me.

Extract (3) focuses on clarifying if the defendant participated in the making of the mask used when burning the car. This example shows how the metastatement leads to the prosecutor's successful adaptation to his institutional power, so that the damaging testimony, i.e. participation in the sewing of the mask, is elicited from the defendant.

In Q1 the prosecutor asks if the defendant had sewed round the hem of the mask worn by his brother when burning the car. Q2 is a pure repetition of Q1. One of the purposes of such repetition of the asked-and-answered question in the previous sequence is, of course, to elicit the damaging testimony from the defendant. Again the defendant disclaims his contribution by wandering away from the topic, i.e. he talks about the cloth wrapping and sweat pants instead of the mask. In courtroom trial, the basic rule governing whether or not evidence is admissible is that it must 
be relevant (cited from Eades 2000). It is clear that what the defendant answers in A2 is irrelevant to the question. He wants to avoid admitting he himself actually sewed the mask used in burning the car for his brother. So the prosecutor adjusts his questioning with the metastatement “我问你面罩呢 (I ask you about the mask)” aiming at specifying the focus -- whether he contributed to the sewing of the mask, which forces the defendant to confess in the following questioning that he did sew the hem of the mask. Institutional power invested to the prosecutor makes such a result possible, and it is a power often employed consciously in the trial process which leads to the successful adaptation.

\section{Conclusion}

In this chapter, we have analyzed courtroom questioning as a dynamic process of adaptation to the institutional power by recourse to intimidation and topic management. Institutional power is one of the three important factors which motivate the questioners' linguistic choice. By adapting their questioning to the institutional power, questioners can succeed in bringing the defendant, especially the hardened criminals, under their control so that their authority as institutional representatives will be maintained, which is essential to ensure the solemnity and effectiveness of courtroom trial. In verbal communication, questions and answers are closely related to each other, but equal attention is not paid to the study of answers. Future research might include the subject of answers in courtroom trial, which remains a topic meriting our scrutiny.

\section{Notes}

${ }^{1}$ Meta-pragmatic awareness is defined as the reflexive awareness involved in the linguistic choice-making process (Vershueren 1999). Jacquemet (1994:123) points out that in courtroom trial metalanguage provides the weapons for a strategy that could distort interaction and hegemonizes the verbal space of participants through intimidation and exclusion. It is further pointed out that this intimidation is usually the exclusive right of the most powerful speakers, and that only the powerful rely on explicit metapragmatic strategies as a form of control.

${ }^{2}$ Metastatement refers to the statement uttered in talking about or describing another statement, and it is an important adaptation strategy for the prosecutor to specify the focus of testifying by recourse to his institutional power.

${ }^{3}$ More often than not, discourse markers or pragmatic markers are used to deal with lexical indications - often sentence adverbs or markers of cohesion and coherence - of how an utterance fits in with surrounding discourse, or of the epistemic and illocutionary status of the prepositional content, or of interpreter-oriented involvement (Verschueren 1999:189).

\section{References}

Carpenter, R. H. (1990). The Statistical Profile of Language Behavior with Machiavellian Intent or While Experiencing Caution and Avoiding Self-Incrimination. Rieber, R. \& Stewart, W. (1990). The Language Scientist as Expert in legal setting: Issues in Forensic Linguistics. The New York Academy of Sciences, New York.

Conley, J., \& O'Barr, W. (1998). Just Words: Law, Language, and Power. The University of Chicago Press.

Drew, P. (1992). Contested Evidence in Courtroom Cross-examination. Talk at Work: Interaction in Institutional Setting. Cambridge University Press.

Eades, D. (2000). I don't think it's an answer to the question: Silencing Aboriginal Witnesses in Court. Language in Society, 29, 161-195. https://doi.org/10.1017/S0047404500002013

Fairclough, N. (1989). Language and Power. Longman.

Hale, S. (1999). Interpreters' Treatment of Discourse Markers in Courtroom Questions. Forensic Linguistics, 6(1), 57-82. https://doi.org/10.1558/sll.1999.6.1.57

Hu, H. J. (2004). A General Review of Courtroom Discourse [J], Journal of Guangdong University of Foreign Studies, $1,8-11$.

Hu, H. J. (2008). A Pragmatic study of Courtroom Questioning Based on Adaptation Theory, [J], Journal of South China Normal University, 5, 154-158.

Hu, H. J. (2019). Courtroom Questioning Adapted to Legal Procedures, Canadian Centre of Science and Education. 12(1), 7-17.

Jacquemet, M. (1994). "If he speaks Italian it's better": Meta pragmatics in Court. Pragmatics 2(2), 111-126. https://doi.org/10.1075/prag.2.2.01jac

Komter, M. (1994). Accusations and Defenses in Courtroom Interaction. Discourse and Society, 5(2), 165-187. https://doi.org/10.1177/0957926594005002002 
Liao, M. Z. (2003). An Interactive Study on Courtroom Questions and Answers, [M], Law Press. Liao, M. Z. (2012). A Framework Analysis of Courtroom Discourse, Contemporary Rhetoric, 6, 2012, 83-91.

Liao, M. Z., \& Gong, J. J. (2015). A Study on Interruption of Court Speech and Gender, Contemporary Rhetoric, 1, 43-45.

Luchjenbroers, J. (1993). Pragmatic Inference in Language Processing. unpublished PhD Dissertation. La Trobe University, Australia

Pan, Q. Y. (1997). Chinese Legal Language Across the Century [M], East China University of Science and Technology Press.

Ran, Y. P. (2008). A Study on the Interpersonal Pragmatic Function of Rhetorical Questions from the perspective of Linguistic Adaptation [J], Modern Foreign Languages.

Rieber, R., \& Stewart, W. (1990). The Language Scientist as Expert in legal setting: Issues in Forensic Linguistics. The New York Academy of Sciences, New York.

Sun, Y. H., \& Zhou, G. Y. (1997). Forensic Linguistics [M], China University of Political Science and Law Press.

Thomas, J. A. (1989). Discourse control in confrontational interaction. The pragmatics of Style. Leo Hickey, London \& New York: Routledge.

Verschueren, J. (1999). Understanding Pragmatics. Edward Arnold Limited.

Walker, A. G. (1987). Linguistic Manipulation, Power and the Legal Setting. Power through Discourse. L. Kedar ed. Norwood, New Jersey: Ablex, 57-82.

Wang, J. (1999). A Study on Legal Language, [M], Guangdong Education Publishing House.

Wu, W. P. (1995). Chinese Evidence versus the Institutionalized Power of English. Forensic Linguistics, 2, $154-167$.

Yuan, C. Y. (2010). The Covert Persuasive Power of the Rhetoric Questions in Lawyers' Defending Arguments [J], Contemporary Rhetoric.

\section{Copyrights}

Copyright for this article is retained by the author(s), with first publication rights granted to the journal.

This is an open-access article distributed under the terms and conditions of the Creative Commons Attribution license which permits unrestricted use, distribution, and reproduction in any medium, provided the original work is properly cited. 